\title{
MECHANISMS FOR THE STIMULATORY AND INHIBITORY EFFECTS OF CARBAMOYLCHOLINE ON CANINE GASTRIC D-CELLS
}

Tsutomu Chiba and Tadataka Yamada

Department of Internal Medicine, The University of Michigan Medical School, Ann Arbor, Michigan

Received July 15, 1987

We have previously reported that carbamoylcholine (carbachol), a recognized inhibitor of somatostatin release from D-cells, can act as stimulant following pretreatment of cells with pertussis toxin. In the present studies we have observed that pertussis toxin reverses the inhibitory effects of carbachol on D-cell stimulated with either cAMP or 12-0tetradecanoyl-phorbol 13-acetate. Furthermore, the stimulatory effects of carbachol on D-cells pretreated with pertussis toxin potentiated the actions of pentagastrin without further enhancing the release of ${ }^{3} \mathrm{H}$-inositol trisphosphate from prelabeled cells. These studies suggest that carbachol exerts its inhibitory effects on D-cells via pertussis toxin sensitive guaninine nucleotide binding proteins at a point distal to the activation of different signal transduction mechanisms and that the stimulatory effects of carbachol are mediated by mechanisms that are independent of membrane phosphoinositide turnover. 1987 Academic Press, Inc

In previous studies we have demonstrated that carbachol, an inhibitor of somatostatin release from gastric D-cells under normal circumstances (1), can stimulate D-cells after pertussis toxin pretreatment (2). The decreased cellular production of adenosine $3^{\prime}: 5^{\prime}$-cyclic monophosphate (cAMP) and enhanced turnover of membrane inositol phospholipids that accompany carbachol action on D-cells suggest possible mechanisms for, respectively, the inhibitory and stimulatory effects that were observed. We undertook these studies to further explore the potential mechanisms for muscarinic regulation of D-cells.

\section{MATERIALS AND METHODS}

Materials: Carbachol, dibutyryl cAMP (dbcAMP), 12-0-tetradecanoyl-phorbol 13acetate (TPA), collagenase I (type I) and ethylenediaminetetra-acetic acid (EDTA) were purchased from Sigma Chemical (St. Louis, MO). Pentagastrin was a product of Peninsula Laboratories (Belmont, $C A$ ) and pertussis toxin was obtained from List Biological Laboratories (Campbell, CA). Earle's balanced salt solution and Ham's F12-Dulbecco's modified Eagle's (50:50, vol/vol) culture media were obtained from Irvine Scientific (Santa Ana, CA). (2-

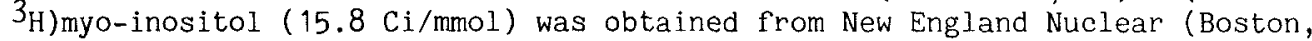
MA), and Dowex-1 resin (100-200 mesh; $x 8$ in the formate form) was purchased from Bio Rad (Richmond, CA).

Cell Isolation and Culture: Mucosal cells were dispersed from stripped canine fundus by sequential exposure to collagenase $(0.35 \mathrm{mg} / \mathrm{ml}$ ) and ETTA ( $1 \mathrm{mM})$, as 
described previously $(1,3)$. Somatostatin containing D-cells were further enriched by centrifugal elutriation and then cultured at a concentration $4 \mathrm{x}$ $10^{6}$ cells/well on a bed of collagen in Ham's F12-Dulbeco's modified Eagle's medium ( $50: 50$, vol/vol) containing 10\% dog serum, insulin ( $8 \mathrm{ug} / \mathrm{ml}$ ) and hydrocortisone $(1 \mathrm{ug} / \mathrm{ml})$ in the presence of $95 \%$ air $-5 \% \mathrm{CO}_{2}$ at $37^{\circ} \mathrm{C}$. After $40 \mathrm{~h}$ of stabilization, the cells were incubated in Earle's balanced salt solution containing various test substances for a subsequent $2 \mathrm{~h}$ experiment and somatostatin released into the media was measured by radioimmunoassay as described previously (4). Some experiments were performed after the cells had been preincubated with pertussis toxin $(200 \mathrm{ng} / \mathrm{ml})$ for $4 \mathrm{~h}$.

Production of $3 \mathrm{H}_{-} \mathrm{IP}_{3}$ : Turnover of membrane inositol phospholipids was


prelabeling for $24 \mathrm{~h}$ at $37^{\circ}$ in culture medium (see above) containing $3_{\mathrm{H}-}$ inositol ( $20 \mathrm{uCi} /$ well). During the last $15 \mathrm{~min}$ of incubation, lithium chloride was added to achieve a final concentration of $10 \mathrm{mM}$. Following the prelabeling period, the cells were further incubated for $5 \mathrm{~min}$ in $1 \mathrm{ml}$ of Earle's balanced salt solution containing various test substances. The incubations were terminated by the addition of $3 \mathrm{ml}$ of chloroform:methanol

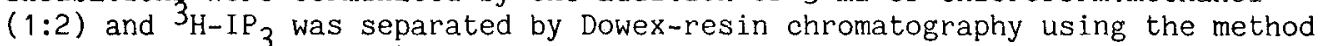
of Fisher and Bartus (5). The fractions denoted as containing $\mathrm{IP}_{3}$ may consist of a mixture of the $1,4,5$ and $1,3,4$ isomers.

\section{RESULTS}

As depicted in Fig. 1, carbachol inhibited the increase in somatostatin release induced by dbcAMP and TPA. Increases in cytosolic ${ }^{3} \mathrm{H}-\mathrm{IP}_{3}$ content were always noted in the presence of carbachol although dbcAMP and TPA by

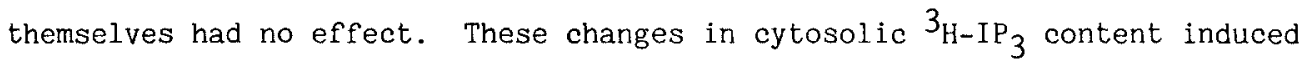

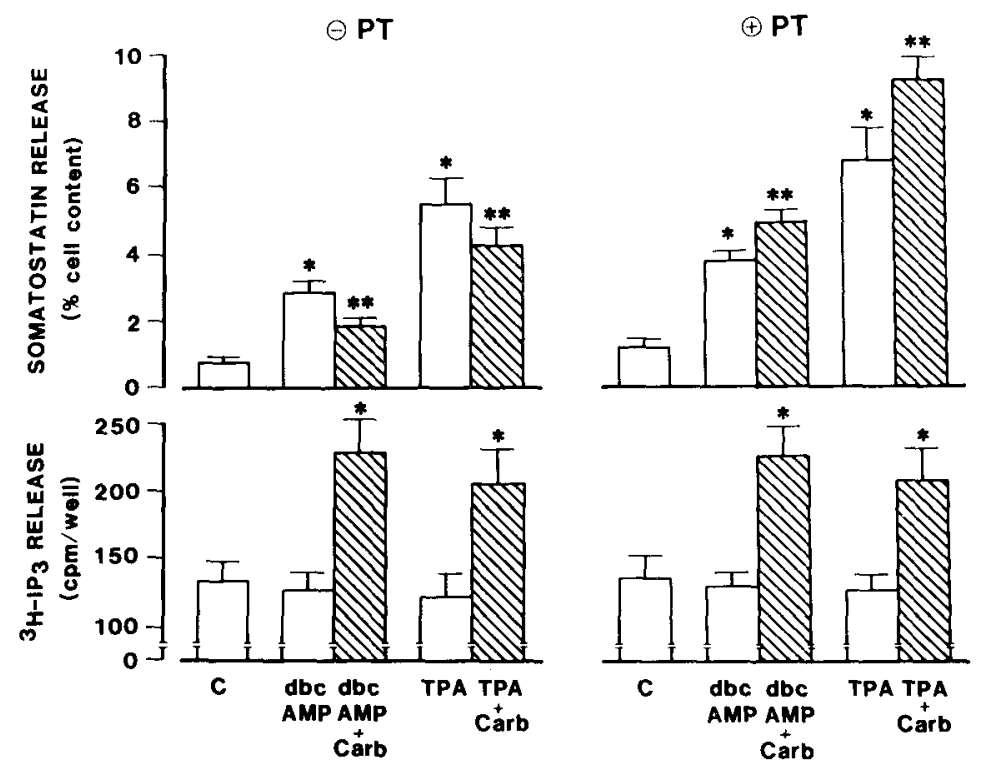

Fig. 1. Effects of pertussis toxin $(200 \mathrm{ng} / \mathrm{ml})$ pretreatment on inhibition of dbcAMP $\left(10^{-9} \mathrm{M}\right)$ - and TPA $\left(10^{-7} \mathrm{M}\right)$-induced somatostatin release by carbachol ( $\mathrm{Carb}, 10^{-4} \mathrm{M}$ ) and on carbachol-induced release of $3 \mathrm{H}_{-1 \mathrm{IP}_{3}}$ from D-cells. Data are presented as means $\pm \mathrm{SE}$ from 4 separate dog preparations and were analyzed using Student's t-tests for paired samples. *P<0.01 vs control (c), **P<0.01 vs dbcAMP or TPA alone. 


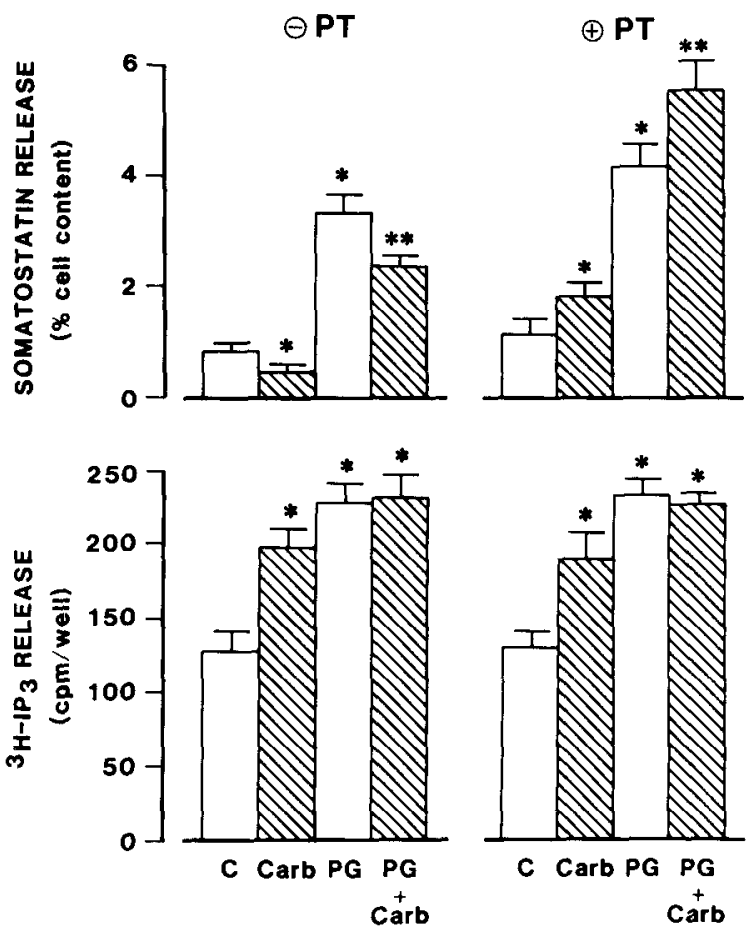

Fig. 2. Effects of pertussis toxin $(200 \mathrm{ng} / \mathrm{ml})$ pretreatment on inhibition of pentagastrin ( $\mathrm{PG}, 10^{-7} \mathrm{M}$ )-induced somatostatin release by carbachol (Carb, $10^{-4} \mathrm{M}$ ) and on carbachol and pentagastrin-induced release of $3_{\mathrm{H}-}$ $\mathrm{IP}_{3}$ from D-cells. Data are presented as means $\pm \mathrm{SE}$ from 4 separate dog preparations and were analyzed using Student's t-tests for paired samples. ${ }^{*} \mathrm{P}<0.01$ vs control (C), **P<0.01 vs PG alone.

by carbachol were unaltered after pre-incubation of D-cells in pertuss is toxin, however, such treatment converted the inhibitory effect of the muscarinic agonist to one in which the stimulatory actions of TPA and dbcAMP were potentiated. In contrast to TPA and dbcAMP, pentagastrin, like carbachol, enhanced $3 \mathrm{H}_{-} \mathrm{IP}_{3}$ production in D-cells (Fig. 2). Carbachol inhibited the stimulatory effect of pentagastrin on somatostatin release

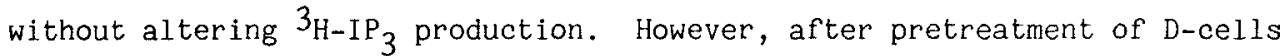
with pertussis toxin, carbachol potentiated the stimulatory effect of pentagastrin on somatostatin release, again without changing the level of ${ }^{3} \mathrm{H}-$ $\mathrm{IP}_{3}$ production.

\section{DISCUSSION}

In previous studies we have observed that inhibition of basal as well as forskolin-stimulated somatostatin release from gastric D-cells is paralleled by decreases in cellular cAMP content, and that these changes could be prevented by pretreatment with pertussis toxin (2). Since pertussis toxin is 
known to inactivate the inhibitory guanine nucleotide binding proteins regulating adenylate cyclase activity by promoting their ADP-ribosylation (6), our data suggest that muscarinic agonists exert their inhibitory effects on Dcells, at least in part, by attenuation of cellular cAMP generation. The present studies indicate, however, that the inhibitory action of muscarinic agonists may occur at a point distal to the production of cAMP since the stimulation of somatostatin release by dbcAMP itself could be inhibited by carbachol in a fashion preventable with pertussis toxin. Moreover, we observed that stimulation of somatostatin release by both TPA and pentagastrin, processes which we have previously demonstrated to be mediated via protein kinase $\mathrm{C}$ activation (7), could also be inhibited by carbachol via a pertussis toxin sensitive pathway. Taken together, these data suggest that muscarinic inhibitory actions on D-cells may be mediated by inhibitory guanine nucleotide regulatory proteins that exert their effects at multiple sites or at some single site at which various signal transduction pathways converge to stimulate D-cells. The mechanisms for such an activity is unknown but may possibly involve such basic processes as phosphoprotein dephosphorylation or ion channel gating, both of which are known guanine nucleotide binding protein dependent actions of cholinergic agonists in other systems $(8,9)$.

We have confirmed our original observations that after pretreatment with pertussis toxin D-cell somatostatin release can be stimulated by carbachol (2). We had speculated previously that this effect might be mediated by the various intracellular signal transduction events triggered by the pertuss is toxin insensitive turnover of membrane phosphoinositides induced by carbachol in D-cells. Furthermore, in the presence of pertussis toxin carbachol potentiated D-cell stimulation by forskolin, an agent known to activate adenylate cyclase directly. However, we noted in the present studies that carbachol was also able to potentiate the stimulation of somatostatin secretion induced by pentagastrin which, as noted above, acts via protein kinase $C$. Furthermore, the potentiating effect of carbachol was not accompanied by a further increment in cytosolic ${ }^{3} \mathrm{H}-\mathrm{IP}_{3}$ content. These data lead us to conclude that the stimulatory effects of carbachol on D-cells may involve additional mechanisms beyond those dependent on membrane phosphoinositide turnover.

\section{ACKNOWLEDGEMENTS}

We gratefully acknowledge the technical support of Jung Park and the secretarial assistance of Lori Ennis. This study was supported by NIH grant R01-DK34306 and funds from the Michigan Gastrointestinal Peptide Research Center (NIH grant P30-DK34933). 


\section{REFERENCES}

1. Yamada, T., Soll, A.H., Park, J., and Elashoff, J. (1984) Am. J. Physiol. 247 (Gastrointest. Liver Physiol. 10), G567-G573.

2. Chiba, T., Raffoul, K., and Yamada, T. (1987) J. Biol. Chem. 262, 84678469.

3. Soll, A.H., Yamada, T., Park, J., and Thomas, L.P. (1984) Am. J. Physiol. (Gastrointest. Liver Physiol. 10), G558-566.

4. Yamada, T., Marshak, D., Basinger, S., Walsh, J., Morley, J., and Stell, W. (1980) Proc. Nat1. Acad. Sci. USA 67, 305-312.

5. Fisher, S.K., and Bartus, R.T. (1985) J. Neurochem. 45, 1085-1095.

6. Kurose, H., Katada, T., Amano, T., and Ui, M. (1983) J. Biol. Chem. 258, $4870-4875$.

7. Chiba, T., Sugano, K., Park, J., and Yamada, T. (1987) Am. J. Physiol. 253 (Gastrointest. Liver Physiol. 16), G62-G67.

8. Lindemann, J.P. and Watanabe, A.M. (1985) J. Biol. Chem. 260, 1312213129.

9. Sasaki, K., and Sato, M. (1987) Nature 325, 259-262. 